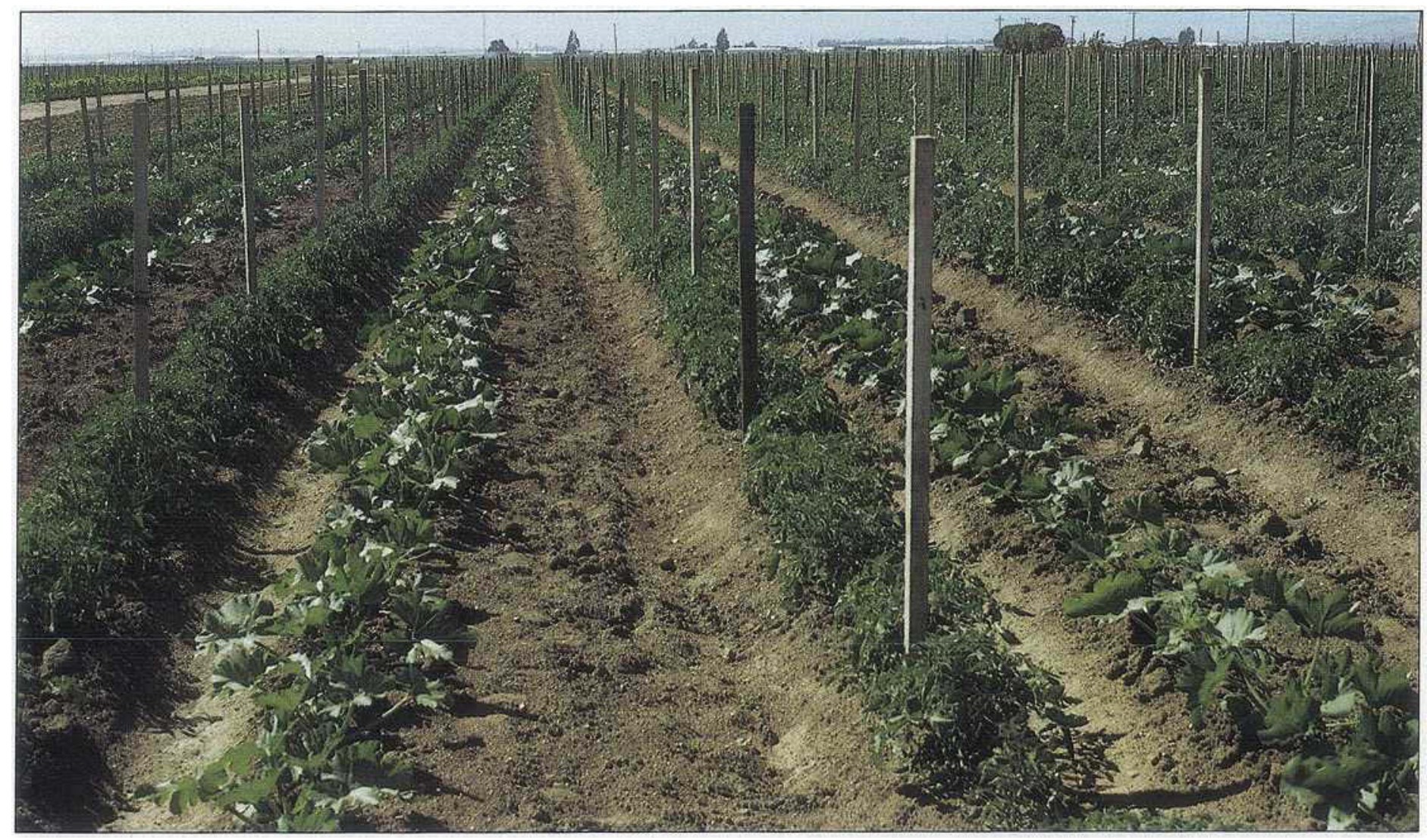

Cherry tomato-zucchini polyculture under farmer management in Salinas Valley.

\title{
Low-input technology proves viable for limited-resource farmers in Salinas Valley
}

\author{
Miguel A. Altieri $\square$ Javier A. Trujillo \\ - Marta A. Astier \\ - Paul L. Gersper \\ 口 Wilhelmus A. Bakx
}

\section{Low-input farming techniques of- fered energy-saving, cost-effective alternatives for resource-poor farmers of Mexican origin in the Salinas Valley. Most of these farm- ers currently manage small acre- ages using intensive vegetable cropping systems and high-input technologies.}

Since its 1985 inception, the Rural DevelopmentCenter (RDC) has been helping lowincome farmworker families become economically self-sufficientfarmers. Established by the Washington D.C.-based Association of Community Based Education (ACBE), the RDC leases each farmworker family 2 to 7 acres of land for a nominal fee, and provides technical and marketing assistance for 3 to 5 years. Most of the 25 families now participating utilize high-input technologies, copying the practices of large-scale commercial growers for whom they have previously worked. However, the conventional methods of large-scale growers, who produce $\$ 700$ million of vegetables annually on 180,000 acres, are seldom appropriate to small-scale farms. Conventional application of chemical pesticides and fertilizers, for instance, is not suited to operations with a reduced economic and resource base

Given the above situation, the Division of Biological Control and Department of Soil Science at the University of California, Berkeley, engaged in a cooperative research, training, and demonstration project with the RDC aimed at assisting these small vegetable growers in developing and adoptinglow-inputagricultural technologies and diversified cropping patterns. Initially, we described existing cropping systems and associated cultural techniques, as well as the biological and socioeconomic constraints affecting the systems.

Through on-farm diagnosis, we identified problems and designed possible solutions. For example, competition from weeds is a common problem. Onecause is inefficient or late weeding, which may result from too little labor, time or capital. Applying herbicides would only add costs and hazards. We developed alternative solutions including crop rotation, intercropping, and weeding at critical competition periods (fig. 1).

During the surveys, we relied heavily on farmers' knowledge of each cropping system and its production potential. Welearned that inputs were not being used efficiently, that land and labor could be used more intensely, that production costs could be lowered, and that agroecological techniques 


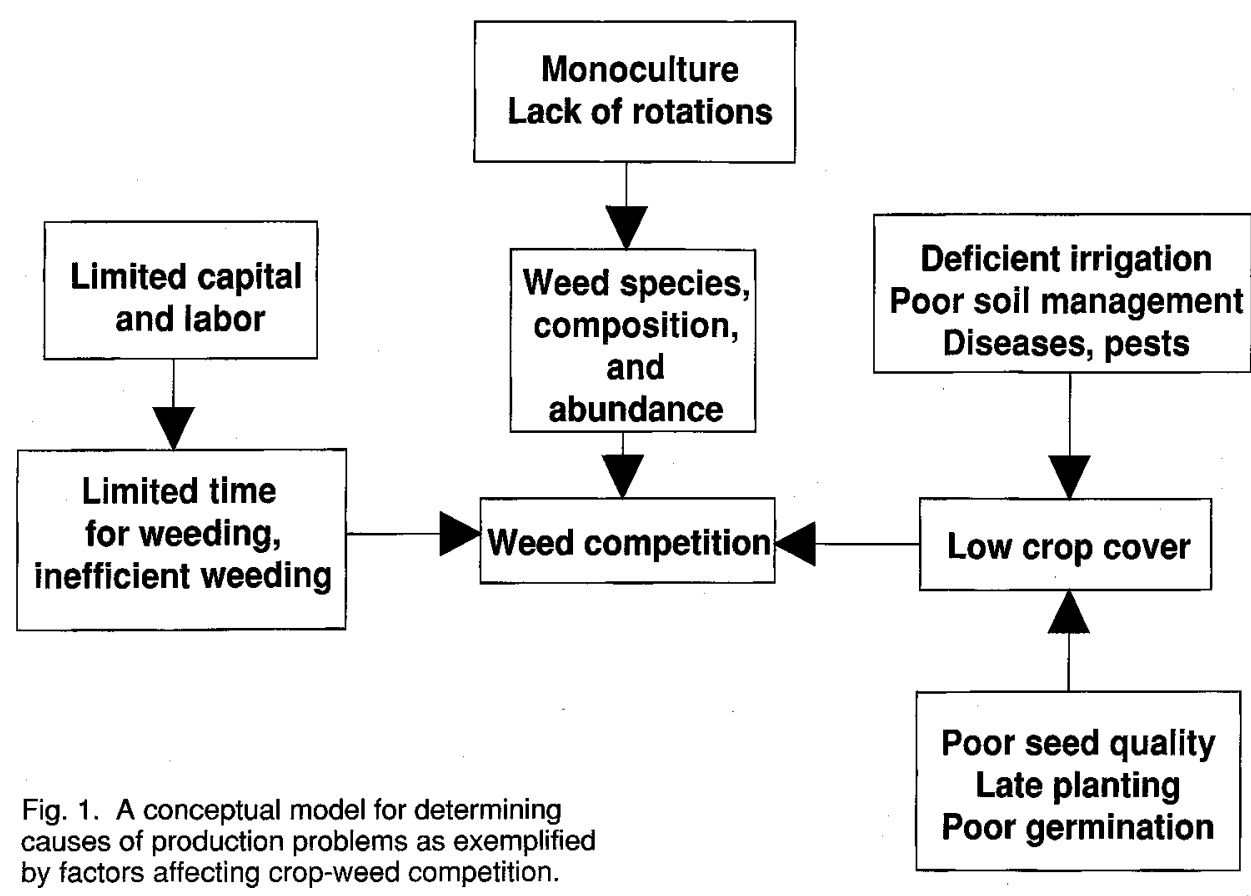

causes of production problems as exemplified by factors affecting crop-weed competition.

\begin{tabular}{|lcc|}
\hline \multicolumn{2}{|c|}{$\begin{array}{c}\text { TABLE 1. Tomato yield under various cultural } \\
\text { management systems in Salinas Valley, } \\
\text { California (1988) }\end{array}$} \\
\hline $\begin{array}{l}\text { Treatment } \\
\text { fruits per plant }\end{array}$ & $\begin{array}{c}\text { Mean no. of } \\
\text { fruits per plant }\end{array}$ \\
\hline $\begin{array}{l}\text { Monoculture } \\
\text { chemically fertilized }\end{array}$ & $1,351.3$ & 172 \\
2-3 weeks weed-free & $1,518.2$ & 178 \\
4-6 weeks weed-free & $1,865.1$ & 220 \\
$\begin{array}{l}\text { Poultry-based compost } \\
\text { amendment }\end{array}$ & $1,604.2$ & 236 \\
$\begin{array}{l}\text { Intercropped with squash } \\
\text { frams }\end{array}$ & $21,639.1$ \\
\hline
\end{tabular}

\section{Experiments}

In a 2-acre area at RDC, we established several cherry tomato, zucchini-squash, and broccoli experimental plots. These included treatments (see table 1) that simulated the farmers' current management methods and comparative treatments that modified these methods. The latter included one or more low-input management components designed to overcome particular constraints and reduce energy use.

Plots were 10 meters square and each treatment was replicated three times. Steer manure was applied at preplanting at a rate of 10 tons per acre. Weed control consisted of maintaining crops weed-free for 2 to 6 weeks after crop emergence, without further weed control after the specified period.

As shown in figure 2, yields of zucchini were similar in systems kept weed-free throughout the season and in systems kept weed-free for 4 to 6 weeks after crop emergence, during all but the last 2 weeks of harvest. Relaxing weed control after the 4to-6 week period provided acceptableyields, with the additional benefit of releasing considerable time for farmers to devote to other tasks. Zucchini plants treated with manure amendment proved more productive than those receiving ammonium sulphate fertilizer applied at the recommended rate of 120 pounds per acre (fig. 3), especially during the last 3 weeks of harvest.

Cherry tomato yields were higher in plots receiving alternative treatments (weed-free periods and composting) than in the chemically fertilized and pesticide-treated monocultures (table 2). The tomato-zucchini polyculture offered a considerable yield advantage. It required 1.02 acres of tomato monoculture and 0.64 acres of zucchini monoculture to produce the same quantities of tomato and squash harvested from only a lacre polyculture. The land equivalent ratio (LER) for tomato and zucchini was 1.66 , which indicates that the total yield of the polyculture per unit area was $66 \%$ greater than for the monoculture.

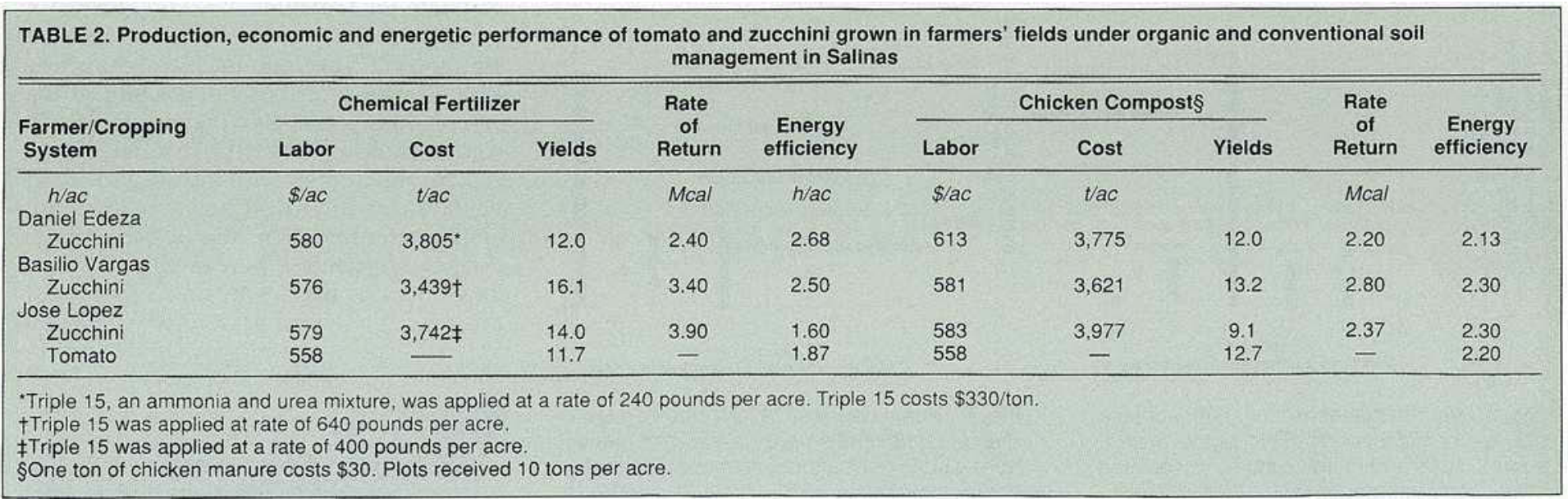




\section{Experiments}

In the spring of 1989, the 2-acre experimental area was planted to plots consisting of cherry tomato monoculture, zucchini monoculture, and tomato-zucchini polyculture, each replicated three times. Poultry-based compost was added to all plots at a rate of 5 tons per acre. All plots were irrigated and tractor-cultivated as required. No chemical fertilizers or pesticides were used.

Data on cropyields, foliar and soil-dwelling pestiferous and beneficial arthropods and pathogens, fluctuations and changes in population levels of weed species, and soil chemical characteristics (soil organic matter content, $\mathrm{pH}$ and nutrient levels) were collected and analyzed. These data helped us compare the performance of the various systems and elucidate the ecological mechanisms that explain observed fluctuations and differences in yield, arthropod, weed, and soil parameters among all systems.

Again, the polyculture overyielded the monocultures as expressed by an LER of 1.48. This yield advantage of the polyculture was due to several factors. Apparently, competition between both crops was mini-

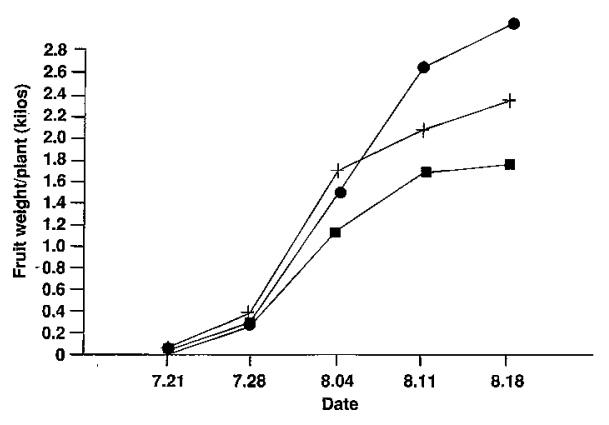

Fig. 2. Yields of zuccini squash under different weeding regimes: $(\bullet)$ weed-free all season, $(\bullet$ ) 2-4 weeks weed-free after transplant, (+) 4-6 weeks weed-free after transplant.

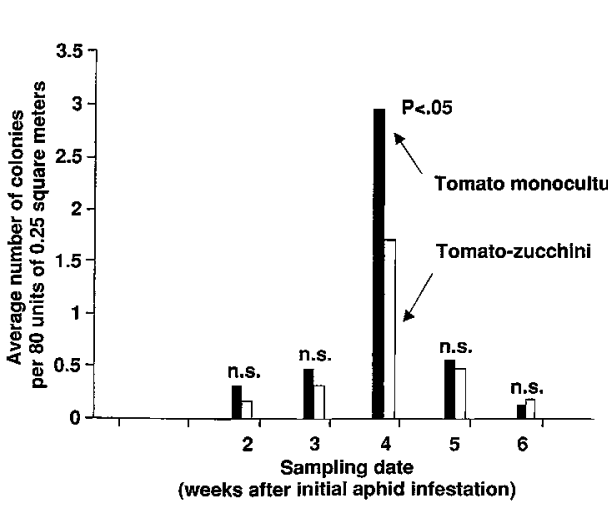

Fig. 4. Abundance of green peach aphid (Myzus persicae) on zucchini plants grown in monoculture and in polycultures associated with cherry tomatoes. mal as their root systems explored different levels of the soil profile; in fact, the combination of both crops seemed to enhance resource capture (water, nutrients). Moreover, the proximity of zucchini plants afforded a certain level of pest protection to tomatoes. During mid-season, tomato monocultures exhibited larger populations of the green peach aphid, Myzus persicae. than the corresponding polycultures (fig. 4).

Although aphid attack was somewhat severe in most zucchini treatment plots, differences in aphid abundance were observed between cropping designs. A faster "crash" in aphid populations was observed in the polycultures, apparently due to the effective mortality imposed by the lady beetles, Hippodamia convergens, whose pupal densities were greater in the polycultures than in monocultures (fig. 5).

Weed suppression through competition or "niche preemption" was very marked in the polycultures, where average weed biomass reached by mid-season was only 8.4 grams per square meter, compared to 248 grams and 88 gramsin the tomatoand squash monoculture, respectively.

The soil at the RDC is a coarse-textured Hanford gravelly sandy loam and is mod-

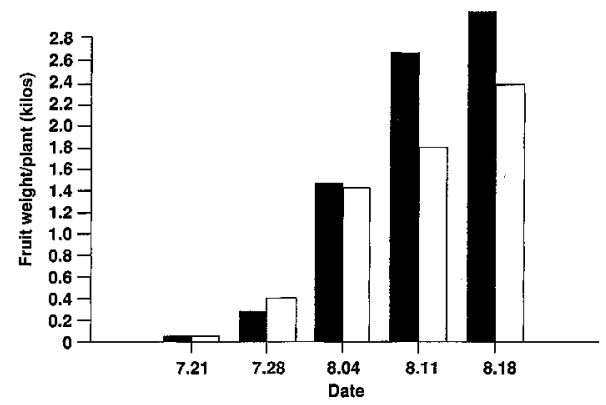

Fig. 3. Yields of zucchini squash under chemical fertilization ( $\square$ ) and steer manure amendment ( $\square$ ).



Fig. 5. Pupal densities of lady-bird beetles (Hippodamia convergens) in zucchini monocultures and in polycultures associated with cherry tomatoes. erately productive with a Soil Conservation Service soil capability rating of IIs -4 and a Storie Index rating of 60 . The productivity of coarse-textured soils increases markedly with increased organic matter, which, in turn, improves tilth and increases nutrients and water-holding capacity. This may lower water and energy requirements for production.

The top soilamended with poultry-based compost, sampled in the spring of 1989 , contained $43 \%$ more organic carbon, $40 \%$ more nitrogen, $8 \%$ more exchangeable calcium, $68 \%$ more exchangeable potassium, $10 \%$ less exchangeable magnesium, and $31 \%$ less exchangeable sodium than nonamended topsoil. After the crops were harvested in the fall, the compost amended topsoil wasstill $16 \%$ higher in organic carbon and $10 \%$ higher in nitrogen.

\section{Experiments in farmers' fields}

Three cooperating farmers each devoted 10 rows of one field to test the application of poultry-based compost (10 tons per acre) on theyields of tomato and zucchini. The rest of the field was managed conventionally using commercial fertilizers and pesticides at various rates (see table 2). Assessments were made of energy efficiency, economic performance, labor requirements and crop productivity. Results showed compost-induced yields to be fairly comparable to that of chemical fertilizers (table 2). Two farmers obtained higher zucchini yields with chemical fertilizers, but they used considerably higher fertilizer dosages than recommended. These larger yields contributed to larger profits and a larger rate of returns. Differences in energy efficiency varied between systems and were not significantly different between organic and conventional plots managed by the same farmers. All organic zucchini systems showed $5 \%$ to $10 \%$ lower labor productivity due to increased labor inputs associated with compost hauling and spreading.

We expect that with time, as farmers who are converting to organic production are well into the transitional period, yields under organic management will increase, ensuring savings in economicand energy costs. With greater availability of organic fertilizers, chemical fertilizers could be replaced by compostatapproximately the same purchase cost for the farmer, with the additional advantages of improved soil structure and better water retention, and possible reductions in nutrient leaching or run-off. These long-term advantages are now being monitored for the second year, and will be subjected to economic evaluation that takes into consideration ecological costs.

\section{Conclusions}

Ourprojectdemonstrates thatitis possible to grow vegetables with low-input, energy- 
conserving technologies in an area where vegetable production traditionally involves high inputs. This can have long-term ecological, socioeconomic, and public health ramifications, but such benefits will become more apparent as the conversion process from high-input to low-input agriculture continues.

As the effects of biological pest control and organic amendments become more evident, we expect that farmers adopting the new systems will beable to reduce energy use, cut costs of production and secure diversity of production for subsistence and marketing. In fact, we expect that the maximum yields sustained by organic methods could be much higher than those now realized. Indirect benefits may include reduced soil erosion, reduced chemical pollution, better water conservation, and increased soil biological activity.

As our collaborating small farmers link to specialty and natural food markets with products either certified as organic or perceived as chemical-free, they will enhance their ability to obtain premium prices for their produce, considerably increasing income.

This project demonstrates the benefits of researchers and farmers working side-byside to design and conduct formal trials of innovative practices, such as low-input and energy-saving systems and technologies. In this way, farmers use their own criteria for evaluating the potential benefits or risks of the proposed systems.

Wehopeour experience provides a model for on-farm research and extension to be used in areas with similar agroclimatic and socioeconomic conditions, benefiting other resource-poor farm workers and farmers who have the talent and ambition to be productive and successful producers.

Miguel A. Altieri is Associate Professor and Associate Entomologist, Division of Biological Control, UC Berkeley; Javier A. Trujillo is Assistant Professor, Colegio de Post Graduados, Chapingo, Mexico; Marta A. Astier is Graduate Student, Department of Soil Science, U.C. Berkeley; P. L. Gersper is Associate Professor and Associate Pedologist, Department of Soil Science, UC Berkeley; and Wilhelmus Bakx is Graduate Student, Department of Soil Science, UC Berkeley.

Support from Richard Amon, California Energy Commission's Small Farm Energy Assistance Program; the Jessie Smith Noyes Foundation, New York; the By-Products Division of Foster Farms, Inc.; and the College of Natural Resources at UC Berkeley are greatly appreciated. C. P. Zachariadis, Executive Director, Association of Community Based Education, Washington, D.C., M. Gonzales, Agronomist, Rural Development Center, Salinas, and Maritza Muñoz, student, Department of Soil Science, U.C. Berkeley provided valuable collaboration in various aspects of the project.

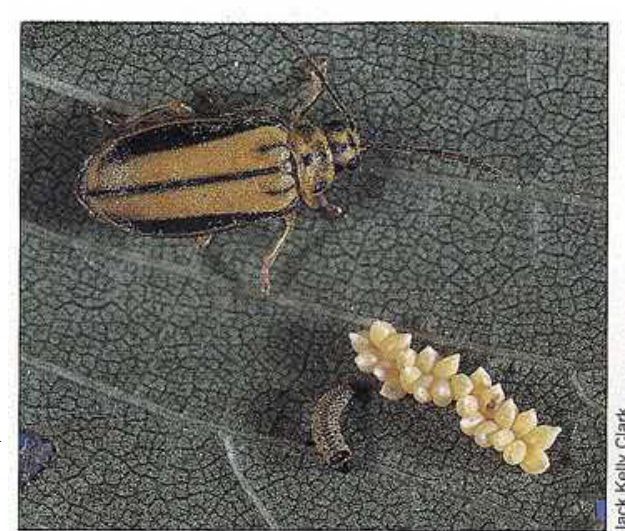

Above: Elm leaf beetle (ELB) adult, egg cluster and early instar larva.

Right: ELB prepupae and pupae, which often collect in huge numbers at the tree base.

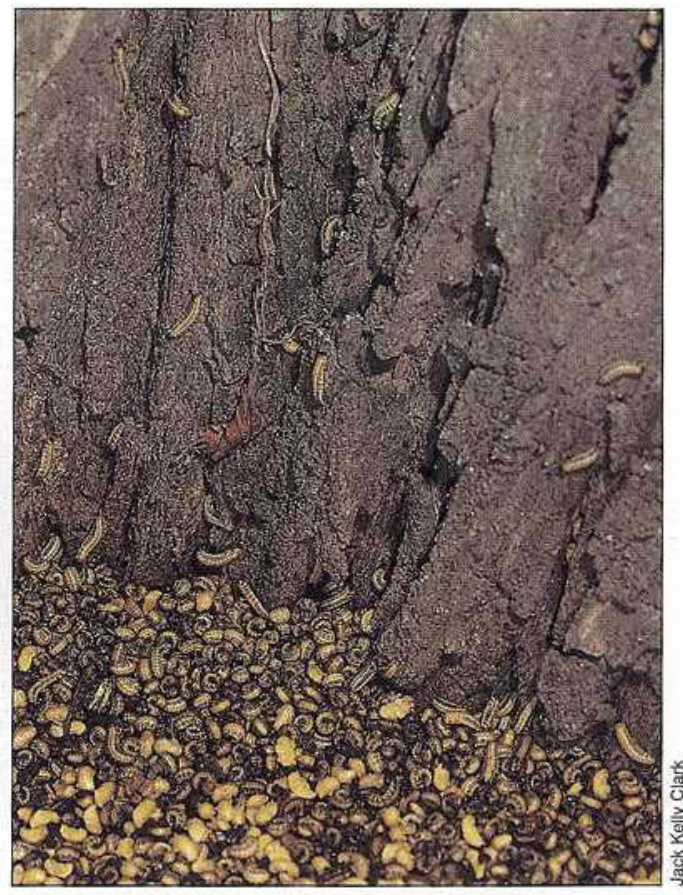

\title{
Treatment of destructive elm leaf beetle should be timed by temperature
}

\author{
Steve H. Dreistadt $\square \quad$ Donald L. Dahlsten $\square \quad$ David L. Rowney \\ Susan M. Tait $\square$ Glen Y. Yokota \ William A. Copper
}

\section{Elm leaf beetle control efforts in northern California can be effec- tively timed using temperature monitoring. Two available control methods are a new biological in- secticide, and an insecticide ap- plied as a bark band. Both meth- ods help preserve the beetle's natural enemies.}

The third most destructive urban forest insect in the western United States, elm leaf beetle (Xanthogaleruca luteola) can cause serious defoliation. In California, it is the most commonly treated pest on an estimated 2.5 million elms. Elm leaf beetle (ELB) is often managed by applying broad-spectrum insecticides to plant leaves, but these applications are expensive, can cause secondary pest outbreaks, and are increasingly unpopular with the public. We have been investigating effective, selective ELB management tools.

ELB was accidentally introduced from Europe to the United States in the 1830s and was first reported in California in the 1920s Adults overwinter in sheltered locations, such as under bark or in buildings, and emerge in the spring to lay eggs on elm foliage shortly after leaves burst. After the three larval instars have fed in the canopy, the mature larvae crawl down the trunk to pupate around the tree base. ELB has one or two generations a year in the 3,000-footelevation or higher communities in Lassen, Modoc, and Shasta Counties in northeastern California, two to three generations in the Sacramento Valley and coastal mountain valleys of northern California, and three or more generations in southern California.

\section{Biological control}

Entomologists haveestablished threeELB parasites in California. Parasitization by Erynniopsis antennata, a small, black tachinid fly, sometimes exceeds $40 \%$ and helps to reduce beetle populations. The oblong, dark reddish pupae of Erynniopsis can be seen during the summer among the greenish beetleprepupaeand yellowish pupaearound the tree base. Tetrastichus brevistigma, a small wasp that emerges from beetle pupae, is less 